\title{
Status of Fluid and Electrolyte Absorption in Cystic Fibrosis
}

\author{
M.M. Reddy ${ }^{1}$ and M. Jackson Stutts ${ }^{2}$ \\ ${ }^{1}$ Department of Pediatrics, UCSD School of Medicine, University of California, San Diego, La Jolla, \\ California 92093 \\ ${ }^{2}$ Department of Physiology, University of North Carolina, Chapel Hill, North Carolina 27599 \\ Correspondence: hoopster@med.unc.edu
}

Salt and fluid absorption is a shared function of many of the body's epithelia, but its use is highly adapted to the varied physiological roles of epithelia-lined organs. These functions vary from control of hydration of outward-facing epithelial surfaces to conservation and regulation of total body volume. In the most general context, salt and fluid absorption is driven by active $\mathrm{Na}^{+}$absorption. $\mathrm{Cl}^{-}$is absorbed passively through various available paths in response to the electrical driving force that results from active $\mathrm{Na}^{+}$absorption. Absorption of salt creates a concentration gradient that causes water to be absorbed passively, provided the epithelium is water permeable. Key differences notwithstanding, the transport elements used for salt and fluid absorption are broadly similar in diverse epithelia, but the regulation of these elements enables salt absorption to be tailored to very different physiological needs. Here we focus on salt absorption by exocrine glands and airway epithelia. In cystic fibrosis, salt and fluid absorption by gland duct epithelia is effectively prevented by the loss of cystic fibrosis transmembrane conductance regulator (CFTR). In airway epithelia, salt and fluid absorption persists, in the absence of CFTR-mediated $\mathrm{Cl}^{-}$secretion. The contrast of these tissue-specific changes in CF tissues is illustrative of how salt and fluid absorption is differentially regulated to accomplish tissue-specific physiological objectives.

\section{ABSORPTION IN GLANDS AND INTESTINES}

Exocrine glands are generally involved in two Emajor physiological functions: secretion of macromolecules such as enzymes and electrolyte fluid into the lumen, and postsecretory modification of primary secretions by a process involving absorption of fluid and electrolytes as they pass through the lumen of the ductal system (Fig. 1). For the sake of simplicity, we can take the sweat gland as a representative example of exocrine structure and function. The sweat gland is a morphologically and physiologically simple exocrine model system. The sweat gland has two morphologically distinct regions: a secretory coil that secretes isotonic fluid into its lumen and a reabsorptive duct that reabsorbs most of the secreted $\mathrm{Na}^{+}, \mathrm{Cl}^{-}$, and $\mathrm{HCO}_{3}^{-}$from the lumen as the primary sweat passes on to the skin surface to evaporate for cooling (Quinton 1987). Secretion of salt into the lumen of the secretory coil serves the primary function of

Editors: John R. Riordan, Richard C. Boucher, and Paul M. Quinton

Additional Perspectives on Cystic Fibrosis available at www.perspectivesinmedicine.org

Copyright (C) 2013 Cold Spring Harbor Laboratory Press; all rights reserved; doi: 10.1101/cshperspect.a009555

Cite this article as Cold Spring Harb Perspect Med 2013;3:a009555 
M.M. Reddy and M.J. Stutts

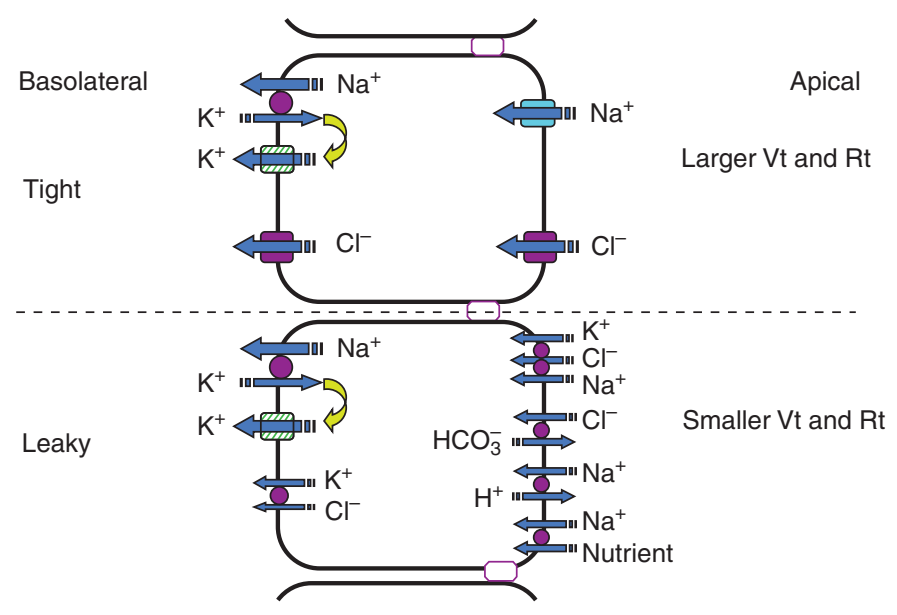

Figure 1. A simplified model depicting significant transport processes in tight and leaky epithelia. Notice that the tight epithelia predominantly depend on the amiloride-sensitive epithelial $\mathrm{Na}^{+}$channel and CFTR anion channel in the apical membranes for transporting $\mathrm{Na}^{+}$and $\mathrm{Cl}^{-}$ions into the cell down the electrochemical gradient. These epithelia are characterized by relatively high electrical resistance (Rt) and transepithelial potentials $(\mathrm{Vt})$. In contrast, the leaky epithelia predominantly depend on carrier-mediated transporters such as $\mathrm{NaK}_{2} \mathrm{Cl}$ and $\mathrm{Na}$ nutrient (e.g., $\mathrm{Na}^{+}$-glucose) cotransporters, $\mathrm{Na}^{+} / \mathrm{H}^{+}$, and $\mathrm{Cl}^{-} / \mathrm{HCO}_{3}^{-}$exchangers across the apical membranes. Leaky epithelia are also characterized by relatively low values of Rt and Vt. Although most epithelia generate a lumen-negative $\mathrm{Vt}$ of varying magnitude, proximal convoluted tubules can generate a lumen-positive $\mathrm{Vt}$ (about $+3 \mathrm{mV}$, attributed to paracellular $\mathrm{Cl}^{-}$diffusion potential) in the absence of nutrient transport and decreased luminal $\mathrm{NaHHCO}_{3}^{-}$concentration (Kokko 1973). Although the $\mathrm{Na}^{+} / \mathrm{K}^{+}$pump plays a major role in the extrusion of $\mathrm{Na}^{+}$from the cell in the salt absorption process, the mechanism of $\mathrm{Cl}^{-}$exit is either mediated by CFTR or by a carrier-mediated transporter such as the $\mathrm{KCl}$ cotransporter in the basolateral membrane.

creating a serosa-to-lumen osmotic gradient to facilitate secretion of water. Because the primary function of the sweat gland is to wet the skin surface for evaporative cooling, losing electrolytes along with water from the body is highly undesirable because it can lead to severe dehydration, electrolyte imbalance, and associated multi-organ disturbances. This physiological threat has been effectively solved in primates as the primary sweat passes through the reabsorptive duct, where most of the secreted salt is returned by active absorption to the extracellular fluid compartment before the sweat deposits onto the skin surface. Most exocrine glands and organs use some variant of this basic principle; that is, first, a primary secretion of an isotonic fluid, followed by a subsequent modification by reabsorption to create a tissue-specific final secretory product so that different exocrine glands exploit this process to create an optimal extracellular aqueous medium to assist in specific physiological functions. For example, although conservation of salt and/ or maintenance of electrolyte balance are the primary goals of the absorptive process in the sweat gland and the kidney tubules (Quinton 1990; Bhalla and Hallows 2008), airway epithelial cells may exploit this absorptive process to maintain proper volume and composition of the airway surface liquid (ASL), which is critical for keeping the airways clear of infections and blockage (Widdicombe and Widdicombe 1995; Welsh 1996; Boucher 2001). The physiological significance of this process is emphasized by the fact that abnormal electrolyte absorptive function can lead to severe pathological conditions such as cystic fibrosis (CF), hypertension, pseudohypoaldosteronism (PHA), and Liddle syndrome (Quinton 1990; Bhalla and Hallows 2008). 


\section{Absorptive Mechanisms Are Tissue Specific}

Epithelial cells welded together by tight junctions can accomplish vectorial transport of $\mathrm{NaCl}$ and water. Epithelial cells are polarized by an apical membrane (APM) and a basolateral membrane (BLM). Each membrane incorporates specific ion channels and transport proteins such that in an absorptive epithelium, $\mathrm{NaCl}$ can enter the cell at the APM and exits the cell across the BLM. Epithelial cells of different exocrine organs use diverse physiological strategies involving coupled ion cotransporters, counter-ion exchangers, and ion channels to absorb salt from the lumen to blood. Significant differences exist in the mechanisms of salt absorption across the apical membranes of different epithelial cells so as to be in compliance with their respective physiological roles in a particular tissue. Because epithelial water permeability varies among tissues, fluid and electrolyte absorption can be either hypo-osmotic (luminal fluid has lower osmolality compared with plasma) (Bijman and Quinton 1984; Quinton 1984) or isotonic (luminal fluid has the same osmolality as plasma). So-called leaky epithelia depend on carrier-mediated $\mathrm{Na}^{+}$-absorptive mechanisms, and they are generally involved in isotonic fluid absorption. In contrast, epithelia using ENaC-dependent active salt transport (e.g., sweat glands, cortical collecting duct, and distal colon) generally tend to be involved in hypo-osmotic absorption (Quinton 1984; Devuyst and Guggino 2002), as described in greater detail in the following discussion.

\section{Isotonic Absorption}

Most "leaky" absorptive epithelia (so-called because of their electrically conductive tight junctions) such as proximal tubules, small intestine, and gallbladder are characterized by the presence of small trans-epithelial electrical potentials and relatively high water permeability. These epithelial cells generally use combinations of carrier-mediated transport components, such as $\mathrm{Na}^{+} / \mathrm{K}^{+} / 2 \mathrm{Cl}^{-}$and $\mathrm{Na}^{+} / \mathrm{Cl}^{-}$cotransporters, as well as $\mathrm{Na}^{+} / \mathrm{H}^{+}$and $\mathrm{Cl}^{-} /$ $\mathrm{HCO}_{3}^{-}$exchangers and $\mathrm{Na}^{+}$-coupled nutrient transporters such as $\mathrm{Na}^{+}$-glucose and $\mathrm{Na}^{+}$-amino acid cotransporters, in the apical membrane (Berschneider et al. 1988; Reuss 1985; Reuss et al. 1991; Kunzelmann and Mall 2002). For example, fluid absorption in the intestine and proximal tubules is always coupled to the movement of solutes from the lumen. There are significant regional differences with respect to the relative role of the aforementioned carrier-mediated transport processes even within the gastrointestinal tract and kidney tubules. For example, $\mathrm{Na}^{+}$-dependent glucose and amino acid transporters play a significant role in the process of absorption in the jejunum and ileal regions. In contrast, varying degrees of contribution from $\mathrm{Na}^{+} / \mathrm{H}^{+}$(NHE) and $\mathrm{Cl}^{-} / \mathrm{HCO}_{3}^{-}$exchangers to fluid absorption is observed from the duodenum to the distal colon (Berschneider et al. 1987; Quinton 1999). Similarly, along the nephron, $\mathrm{Na}^{+}$-dependent nutrient transporters (e.g., $\mathrm{Na}^{+}$-glucose cotransporters) in the proximal tubule, NHE in the early proximal convoluted tubules, $\mathrm{NaCl}$ cotransporters in the distal convoluted tubules, and $\mathrm{Na}^{+} / \mathrm{K}^{+} / 2 \mathrm{Cl}^{-}$cotransporters and NHE in the thick ascending limb (Quinton 2007) play tissue-specific roles in absorptive processes. Even though defective functions of these transporters are associated with several disease conditions in various leaky epithelia, most of the abnormalities in carrier-meditated transport processes in cystic fibrosis appear to be secondary to abnormal CFTR (cystic fibrosis transmembrane conductance regulator) - mediated $\mathrm{Cl}^{-}$permeability, as discussed below.

\section{Hypertonic Absorption}

In contrast to leaky epithelia, the so-called tight epithelia are generally characterized by the presence of relatively large lumen negative trans-epithelial potentials $(<-10 \mathrm{mV}$, lumen negative) and ion channels involved in electrogenic absorption of $\mathrm{NaCl}$ (Boucher et al. 1991; Quinton 1999; Reddy et al. 1999; Kunzelmann and Mall 2002; Reddy and Quinton 2002). These epithelia are mostly, if not exclusively, involved in hypertonic (with reference to plasma) salt absorption and therefore tend to be relatively water impermeable. The human sweat duct, cortical 
M.M. Reddy and M.J. Stutts

collecting duct, colon, and salivary glandular ducts are examples that share these properties. The absorptive process in tight epithelia is predominantly mediated by $\mathrm{ENaC}$ channels and CFTR anion channels in the APM (Reuss et al. 1991; Stutts et al. 1995; Reddy et al. 1999; Kunzelmann and Mall 2002), which involves the following steps: $\mathrm{Na}^{+}$enters the cells via $\mathrm{ENaC}$ channels down a favorable electrochemical gradient, making the cytosolic side of the apical membrane more positive and thereby creating a more favorable electrochemical gradient for negatively charged $\mathrm{Cl}^{-}$ions to enter the cells passively via CFTR $\mathrm{Cl}^{-}$channels. Intracellular $\mathrm{Na}^{+}$is pumped out of the cell by the $\mathrm{Na}^{+} / \mathrm{K}^{+}$ pump in the BLM, which pumps three $\mathrm{Na}^{+}$ions out of the cell in exchange for two $\mathrm{K}^{+}$ions. Hence, the $\mathrm{Na}^{+} / \mathrm{K}^{+}$pump exports one net positive charge out of the cell, thereby contributing slightly to the negative electrical potential of the cell. $\mathrm{Cl}^{-}$entering the cell is driven out across the BLM through $\mathrm{Cl}^{-}$channels down a favorable electrical gradient created by a more negative basolateral membrane potential (Welsh 1987; Reddy and Quinton 1991, 1994; Smith et al. 1996; Kunzelmann and Mall 2002). The BLM of epithelial cells expresses a predominant $\mathrm{K}^{+}$ ion selectivity. The basolateral $\mathrm{K}^{+}$channels not only provide a leakage pathway for extrusion of excess $\mathrm{K}^{+}$accumulated during pump activity but also play a significant role in maintaining trans-epithelial electrical potential due to significantly larger hyperpolarization of BLM relative to the apical membrane potential, thereby providing a significant driving force for vectorial salt transport by epithelial cells (Reddy and Quinton 1987, 1991; Kunzelmann and Mall 2002). Although the salt absorption creates an osmotic gradient from lumen to serosa (blood side), water movement across the tight epithelia down the osmotic gradient is limited by the epithelial barrier to water.

\section{CFTR in Salt Absorption}

CFTR plays a crucial role in diverse physiological functions (regarding absorption and secretion of salt) by numerous epithelial organs (Quinton 1999). CFTR is also unique among ion channels with respect to (1) complex molecular structure (Riordan et al. 1989; Welsh et al. 1992); (2) multiple regulatory controls involving PKC (Berger et al. 1993; Jia et al. 1997), PKA (Cheng et al. 1991; Berger et al. 1993; Dulhanty and Riordan 1994), PKG (Picciotto et al. 1992; French et al. 1995; Vaandrager et al. 1996, 1998), $\mathrm{Ca}^{2+}$ calmodulin-dependent protein kinases (Picciotto et al. 1992), protein tyrosine kinases (Gadsby and Nairn 1999), and different protein phosphatases (Berger et al. 1993; Fischer et al. 1998; Luo et al. 1998; Gadsby and Nairn 1999); and (3) multifunctional behavior involving several transport functions (Schwiebert et al. 1999). Structurally, it is distinguished from most ion channels by the presence of a regulatory domain (R-domain) with multiple consensus phosphorylation sites and two nucleotide-binding domains (NBDs) (Riordan et al. 1989; Welsh et al. 1992). Even though these studies implicated several kinases and phosphatases regulating this channel, we do not know whether all of these regulatory processes are tissue specific or coexist within most epithelial cells. Even if these control mechanisms do exist in vivo, the purpose of such complex regulation remains puzzling. CFTR regulation involves both hydrolytic and nonhydrolytic ATP binding to NBDs (Anderson et al. 1991; Quinton and Reddy 1991; Ko and Pedersen 1995; Reddy and Quinton 1996; Randak et al. 1997; Sheppard and Welsh 1999). Nonhydrolytic ATP binding may be required for coupling transepithelial electrolyte transport to cellular energy charge (Quinton and Reddy 1991). However, it is intriguing that, unlike most ion channels that allow passive diffusion of ions (as opposed to energy-dependent active transport), CFTR uses ATP energy during the transport process. Recent studies have indicated that these multiple controls may play a role in determining the anion selectivity of the CFTR channel to $\mathrm{HCO}_{3}^{-}$and $\mathrm{Cl}^{-}$(Reddy and Quinton 2003b). Thus, understanding the regulatory mechanisms is essential not only to better understand how different mutations selectively affect epithelial $\mathrm{Cl}^{-}$and $\mathrm{HCO}_{3}^{-}$conductances in CF (Reddy and Quinton 2003b), but also to develop effective therapeutic strategies to treat diseases like CF. 


\section{ENaC in Salt Absorption}

The central role that $\mathrm{ENaC}$ plays in salt absorption in several diseases including pseudohypoaldosteronism (PHA), Liddle syndrome, and cystic fibrosis (Schild et al. 1995; Rossier 1996; Hummler and Horisberger 1999; Pilewski and Frizzell 1999; Schreiber et al. 1999; Schwiebert et al. 1999; de La Rosa et al. 2000) emphasizes the clinical and physiological significance of this cation channel in epithelial tissues (Quinton 2007). ENaC is expressed in the APM of cells in the salivary gland ducts, sweat gland ducts, cortical collecting tubules of the kidney, the distal colon, and the airways (Duc et al. 1994; Fuller et al. 1995; Stutts et al. 1995; Rossier 1996). ENaC channels in the kidney are directly involved in the maintenance of extracellular volume and blood pressure and indirectly involved in the homeostasis of $\mathrm{K}^{+}$and $\mathrm{H}^{+}$ions. The reabsorption of $\mathrm{Na}^{+}$in the cortical collecting tubule generates a lumen-negative potential that facilitates the secretion of $\mathrm{K}^{+}$and $\mathrm{H}^{+}$by the distal nephron. Blocking ENaC with amiloride or inactivation by mutation leads to $\mathrm{Na}^{+}$wasting, hyperkalemia, and metabolic acidosis. Many regulatory mechanisms such as the renin-angiotensin-aldosterone axis, antidiuretic hormone, and catecholamines modulate the activity of the $\mathrm{ENaC}$ channels (de La Rosa et al. 2000). ENaC channels are expressed in the respiratory tract from the nose to the alveoli (de La Rosa et al. 2000). In the lung, ENaC activity is necessary for fluid handling, in particular at birth when the transition from a liquid-filled lung occurs (de La Rosa et al. 2000). The composition of the fluid produced by secretory organs such as salivary glands and sweat glands is also modified by ENaC channels located along the ducts that reabsorb luminal $\mathrm{Na}^{+}$.

\section{CFTR-ENaC Coordination in the Apical Membrane}

Studies on the sweat duct indicated that ENaC and CFTR activation are closely coupled but possibly independent of contemporaneous phosphorylation by PKA, which may suggest molecular interactions between the two channel proteins. The carboxy-terminal motif interacting with PDZ1 or PDZ2 of EBP50 (ERM-binding phosphoprotein 50) or other related proteins may be important for some aspects of CFTR function (Hall et al. 1998; Short et al. 1998), which might include CFTR-ENaC interactions. However, we do not know how closely the two channels function in vivo. Recent studies also indicated that activating G-proteins and A and G-kinases stimulate both CFTR and $\mathrm{ENaC}$ simultaneously in the human sweat duct. However, we do not know whether such activation is due to direct action of the agonists on the individual channels or to indirect effects through CFTR interacting with ENaC. Secondary changes in intracellular ion composition seem to control ENaC as well as CFTR channel functions in a complex fashion. Several studies have shown that increasing intracellular $\mathrm{Cl}^{-}$ concentration inhibits ENaC activity (Cook et al. 1998; Kunzelmann and Mall 2002; Reddy and Quinton 2003a). It is important to note that activation of CFTR was shown to inhibit $\mathrm{ENaC}$ activity in some experimental model systems indicating that changes in intracellular $\mathrm{Cl}^{-}$activity could be one of the mechanisms by which $\mathrm{ENaC}$ is inhibited (Dinudom et al. 1993; Reddy and Quinton 2002). Other studies have also indicated that ENaC activity and resultant increases in intracellular $\mathrm{Na}^{+}$cause feedback inhibition of ENaC (Dinudom et al. 1993). Changing intracellular $\mathrm{Na}^{+}$could have indirect effects on $\mathrm{ENaC}$ activity through changing intracellular $\mathrm{pH}$ mediated by basolateral NHE activity (Fig. 2) (Reddy et al. 2008).

\section{Cell Specificity of ENaC-CFTR Interaction}

Studies on the human airway epithelium found increased $\mathrm{Na}^{+}$absorption in CF airways, and some studies in heterologous systems (Boucher 1994b; Knowles et al. 1997; Guggino 1999; Pilewski and Frizzell 1999; Schwiebert et al. 1999) detected a negative influence on $\mathrm{ENaC}$ activity. No evidence of reciprocal coupling between $\mathrm{ENaC}$ exists in other native tissues where it has been studied, such as the sweat duct. It is possible that physiological tissue-specific functions such as absorption versus secretion determine 
M.M. Reddy and M.J. Stutts

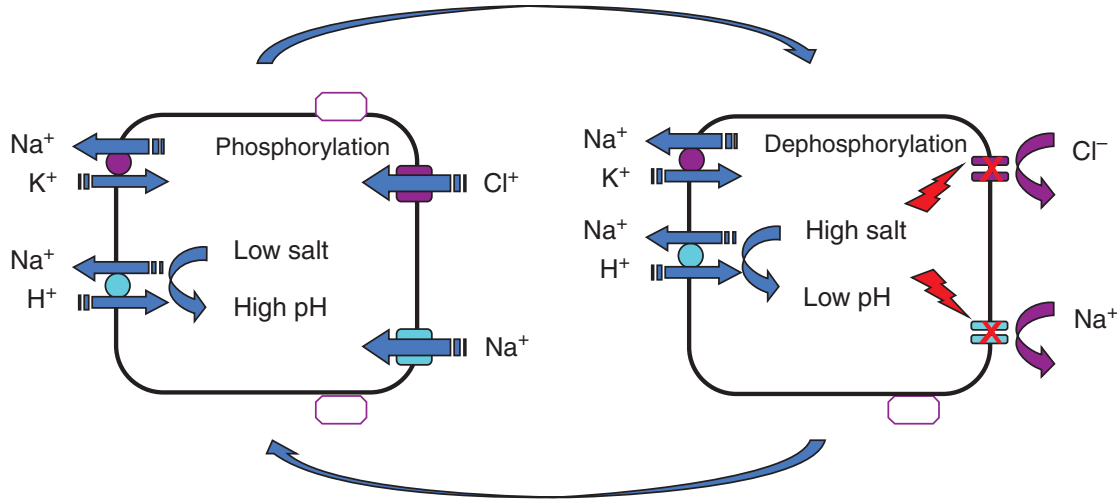

Figure 2. A simplified model depicting feedback regulation of salt absorption. The model illustrates that as intracellular $\mathrm{Na}^{+}$concentration rises as a function of $\mathrm{ENaC}$ activity, the chemical driving force for proton extrusion by the $\mathrm{Na}^{+} / \mathrm{H}^{+}$exchanger (NHE) in the basolateral membrane decreases and allows cytosolic acidification that would negatively feedback and inhibit both ENaC and CFTR activity and limit salt influx across the apical membrane. The feedback inhibition of salt entry would relax as $\mathrm{Na}^{+}$is extruded by the $\mathrm{Na}^{+} / \mathrm{K}^{+}$pump in the basolateral membrane. Prevention of salt influx in excess of pump capacity would protect the absorptive cell from disruptive changes in cell volume during trans-epithelial salt absorption.

the type of CFTR-ENaC interaction or complicate the interpretation of results. However, in heterologous systems, overexpressed proteins may very well skew or adversely affect normal physiological function. For example, in CFPAC-1 cells, hyperexpressing CFTR actually depressed outward-rectifying $\mathrm{Cl}^{-}$currents and inward-rectifying $\mathrm{K}^{+}$currents (MohammadPanah et al. 1998). Native airway tissues and primary cultures of airway epithelia consist of multiple cell types, some of which may secrete while others absorb $\mathrm{NaCl}$ (Welsh 1987; Pilewski and Frizzell 1999). This possibility raises the question of whether the proportional activities of ENaC and CFTR seen in the sweat duct might be present in some cells but overshadowed by functions of others, in more complicated tissues. That is, cAMP-mediated secretion is decreased or absent in CF epithelia (Boucher 1994b; Sato and Sato 1984; Quinton 1999) so that a relatively greater loss of secretory transport in the presence of simultaneous absorptive transport could result in an apparent net increase in $\mathrm{Na}^{+}$absorption relative to normal tissue (Boucher et al. 1988). In fact, some studies on human airways suggested an increase in salt concentration in CF airway surface fluid (Joris et al. 1993; Zabner et al. 1998; Quinton 1999).
These observations seem consistent with recent reports suggesting that increased salt concentration in airway surface fluid may compromise airway defense mechanisms in CF (Smith et al. 1996; Goldman et al. 1997). Furthermore, recent studies involving human airway epithelia (Itani et al. 2011), the $\mathrm{CFTR}^{-/-}$, and $\mathrm{CFTR}^{\Delta \mathrm{F} 508 / \Delta \mathrm{F} 508}$ (Chen et al. 2010; Ostedgaard et al. 2011) have shown reduced $\mathrm{Cl}^{-}$but not $\mathrm{Na}^{+}$conductance in CF airways. Furthermore, a recent study on the relationship between airway epithelial $\mathrm{Cl}^{-}$secretion and $\mathrm{Na}^{+}$absorption balance has led to the conclusion that hCFTR overexpression increases basal secretion but does not regulate $\mathrm{Na}^{+}$transport in wildtype mice (Grubb et al. 2012). A consensus on this topic is still much needed.

\section{EFFECT OF CF ON THE ABSORPTIVE PROCESSES}

\section{Sweat Duct}

Absorption of $\mathrm{NaCl}$ follows the previously described classic model of salt absorption by epithelia involved in hypertonic absorption. $\mathrm{Na}^{+}$and $\mathrm{Cl}^{-}$ions enter the cell via ENaC and CFTR channels in the APM. Intracellular $\mathrm{Na}^{+}$is 
pumped out by the $\mathrm{Na}^{+} / \mathrm{K}^{+}$pump in the BLM. $\mathrm{Cl}^{-}$diffuses out of the cells through basolateral $\mathrm{CFTR} \mathrm{Cl}^{-}$channels. It was shown that the CFTR anion channels are absent in both the BLM and APM of sweat ducts isolated from CF patients. Lack of functional expression of CFTR prevents $\mathrm{Cl}^{-}$exit across the BLM of CF cells (Reddy and Quinton 1992). In addition, absence of CFTR in the APM of CF cells prevents lumen-to-cell $\mathrm{Cl}^{-}$diffusion and causes significant depolarization (makes the membrane more positive) of the apical membrane potential (Reddy and Quinton 1989). APM depolarization abolishes the electrical driving force and prevents passive diffusion of $\mathrm{Na}^{+}$. As a consequence, both $\mathrm{Na}^{+}$and $\mathrm{Cl}^{-}$ions are retained in the lumen, causing significant loss of electrolytes during sweating, particularly in patients afflicted by overheating (Quinton 1999). Thus, elevated sweat $\mathrm{NaCl}$ concentration is the basis of the classic pilocarpine-induced sweat test as a diagnostic feature of CF disease (Quinton 1999).

\section{Salivary Glands}

The physiology of salivary glands seems to follow the classic pattern of exocrine function in which the acinar cells of the salivary glands secrete an isotonic fluid, and the ductal system reabsorbs the salt from the primary secretion. The functional properties of salivary gland ducts appear to mimic closely those of the duct cells that are involved in hypertonic absorption of salt from the lumen using $\mathrm{ENaC}$ and CFTR channels. Salt absorption by the salivary ducts were significantly inhibited by amiloride and CFTR $_{\text {inh }}-172$ in mouse salivary gland ducts (Catalan et al. 2010). Unlike in the airways, where CFTR seems to inhibit ENaC activity, there is a coordinated activation of CFTR and $\mathrm{ENaC}$ in the salivary duct cells so that inhibition of CFTR in the CF mice resulted in the increase in both $\mathrm{Na}^{+}$and $\mathrm{Cl}^{-}$concentrations (Reddy et al. 1999; Catalan et al. 2010). There are inconsistent and conflicting reports on the effect of CF on salivary gland functions. Abnormal $\mathrm{Cl}^{-}$absorption and $\mathrm{HCO}_{3}^{-}$secretions by the submandibular gland ducts were ob- served from CF patients (Blomfield et al. 1973; Davies et al. 1989, 1991; McPherson et al. 1992). Several studies have indicated functional and pathological abnormalities in salivary gland functions. It is well known that CFTR and $\mathrm{ENaC}$ channels play a predominant role in hypertonic salt absorption in human salivary gland ducts. Early studies indicate elevated $\mathrm{NaCl}$ concentration in the parotid gland secretion from CF patients (Prader and Gautier 1955; di Sant'Agnese 1956; Johnson 1956; Barbero and Sibinga 1962). Increased levels of $\mathrm{NaCl}$ (and defective $\beta$-adrenergic secretions) (Bergler et al. 1994a,b; Catalan et al. 2010) were also observed in the submandibular secretions from mice with the $\Delta$ F508 CFTR mutation (Catalan et al. 2010).

\section{Small Intestine}

There are conflicting reports on the effect of CF on absorptive process in the intestine. $\mathrm{Na}^{+}$-dependent nutrient transport is the predominant mechanism of absorption in the small intestine. Early reports indicated enhanced $\mathrm{Na}^{+}$-dependent glucose cotransport (Frase et al. 1985). These observations were supported by the subsequent studies showing increased nutrientdependent short circuit currents (Baxter et al. 1988, 1989, 1990a,b; Hardcastle et al. 1990; Teune et al. 1996). It is well known that secretion of electrolyte fluid is severely compromised throughout the intestine including the jejunum and ileum (Berschneider et al. 1987, 1988; Taylor et al. 1987, 1988). Because the nutrient absorption is driven by the driving force for $\mathrm{Na}^{+}$, absence of a $\mathrm{Cl}^{-}$shunt due to lack of CFTR anion channels in the plasma membranes of CF intestinal epithelium seems to increase the driving force for $\mathrm{Na}^{+}$, causing a significant surge in glucose and other nutrient absorption. To have an increased driving force for $\mathrm{Na}^{+}$glucose cotransport, it seems necessary that both CFTR and $\mathrm{Na}^{+}$-dependent cotransporters must be present in the plasma membranes of the same cell. In fact, $\mathrm{a} \mathrm{Cl}^{-}$conductance resembling CFTR is colocalized with $\mathrm{Na}^{+} /$glucose cotransport in rat and human small intestine, supporting the possibility that abnormalities in glucose 
M.M. Reddy and M.J. Stutts

absorption in cystic fibrosis may be a secondary effect of defects in $\mathrm{Cl}^{-}$channel function (Baxter et al. 1990a,b; Hardcastle et al. 1990). Russo et al. (2003) have reported that fluid absorption processes are, in fact, reduced in CF jejunum because of a marked depression of passive chloride absorption, but that $\mathrm{Na}^{+}$-glucose cotransport in the CF jejunum is normal. In contrast to human intestine, intestinal glucose absorption seems reduced in transgenic mouse models of CF with the $\Delta$ F508 mutation. Therefore, it was suggested that the transgenic mouse models of CF might not accurately reflect all aspects of intestinal dysfunction in the human disease (Hardcastle et al. 2004). It was further reported that the Cftr-null mice lacking one or both copies of the NHE3 $\left(\mathrm{Na}^{+} / \mathrm{H}^{+}\right.$exchanger $)$gene exhibited increased fluidity of their intestinal contents, which prevented the formation of obstructions and increased survival (Bradford et al. 2009), indicating that salt absorption in the face of reduced secretions caused by CFTR mutations plays a significant role in the development of intestinal pathology in CF mice. However, increased $\mathrm{Na}^{+}$-dependent nutrient and fluid absorption in the face of reduced CFTR-dependent $\mathrm{Cl}^{-}$secretion in CF intestinal epithelium appears to be a primary cause of dehydrated luminal content leading to the pathogenesis of meconium ileus in CF patients (Berschneider et al. 1988).

\section{Colon}

Electrolyte and fluid absorption is the predominant function of the colonic epithelium. The human colon absorbs large quantities of fluid and electrolytes per day $(\sim 1.5 \mathrm{~L} / \mathrm{d}$ ) (Debongnie and Phillips 1978). Absorptive processes in the colon are complex and exhibit significant regional differences. In the ascending colon, electroneutral transport involving $\mathrm{Na}^{+} / \mathrm{H}^{+}$ and $\mathrm{Cl}^{-} / \mathrm{HCO}_{3}^{-}$exchangers seems to be the predominant mechanism of absorption. In contrast, electrogenic absorption involving $\mathrm{ENaC}$ and CFTR channels appears to play a significant role in electrolyte fluid absorption in the descending colon (Clauss et al. 1985; Kunzelmann et al. 2001; Kunzelmann and Mall 2002). Defects in the absorptive processes were observed in both electroneutral as well as electrogenic components of colonic absorptive processes (Kunzelmann and Mall 2001, 2002). Early studies on CF mouse colons show increased electrogenic sodium absorption compared with wild-type tissues. Elevated plasma aldosterone in CF mice was suspected to be responsible for part or all of the increased sodium absorption in CF mouse colons (Cuthbert et al. 1994, 1999). It was also reported that in both CFTR knockout mice and in CF patients, the absence of CFTR-mediated inhibition of ENaC seems responsible for increased amiloride-sensitive short-circuit currents and $\mathrm{Na}^{+}$absorption in the colonic epithelium compared with non-CF controls (Grubb and Boucher 1997; Briel et al. 1998; Mall et al. 1999; Kunzelmann and Mall 2001; Kunzelmann et al. 2001).

\section{Isotonic Salt Absorption by Airway Epithelia}

The essential physiological purpose of human airways is to conduct inspired air to and from the alveolar surfaces where gas exchange occurs. Structurally, the lower airways dichotomously branch from the trachea $(\sim 2 \mathrm{~cm}$ diameter $)$ to thousands of terminal airways $(0.5-1 \mathrm{~mm}$ diameter) (Kilburn 1974). The large aggregate surface of these conducting airways is lined by a continuous epithelium that is protected from desiccation by a thin $(\sim 10 \mu \mathrm{m})$ liquid layer called airway surface liquid (ASL). Additionally, ASL supports the innate immune defense mechanism of mucociliary clearance of particles deposited from inhaled air, including infectious agents (Knowles and Boucher 2002). The airway mucosal surface is kept hydrated and mucociliary clearance is maintained by regulation of ASL volume and composition through the fluid transport activities and passive barrier properties of airway epithelia (Boucher 1994a). Airway epithelia are equipped both to absorb $\mathrm{Na}^{+}$and secrete $\mathrm{Cl}^{-}$, indicative of the importance of regulating airway surface hydration. Electroneutrality requires that $\mathrm{Na}^{+}$cannot be absorbed without a co-ion, predominantly $\mathrm{Cl}^{-}$, and neither can $\mathrm{Cl}^{-}$be secreted without an co-ion, predominantly $\mathrm{Na}^{+}$. Thus, ASL 
homeostasis is achieved by balanced isotonic salt absorption and secretion.

\section{Path for $\mathrm{Na}^{+}$Absorption}

Airway epithelia are composed of ciliated and nonciliated cells (Kreda et al. 2005). Ciliated cells not only elaborate the cilia that move ASL cephalad, but are also the cells that accomplish salt transport. Nonciliated cells secrete macromolecules, used in innate defense, including mucins, whose physicochemical properties are dependent on hydration (Kesimer et al. 2010). The path for $\mathrm{Na}^{+}$absorption through ciliated cells consists of entry at the apical membrane and extrusion from the basolateral membrane. Entry of $\mathrm{Na}^{+}$from ASL is rate limiting for $\mathrm{Na}^{+}$ absorption and is primarily mediated by the epithelial $\mathrm{Na}^{+}$channel (ENaC). Other means of $\mathrm{Na}^{+}$entry have been considered, such as $\mathrm{Na}^{+}$/ proton exchange or $\mathrm{Na}^{+} /$glucose cotransport, but have not been found to play a major role in airway epithelia. $\mathrm{Na}^{+}$extrusion across the basolateral membrane is accomplished by $\mathrm{Na}^{+}-\mathrm{K}^{+}$-ATPase (Knowles et al. 1984). This transport element is obviously essential for $\mathrm{Na}^{+}$absorption by all epithelia, but it does not appear to be the point of regulation in airway epithelia. Thus, $\mathrm{Na}^{+}$absorption in airways is regulated principally at the $\mathrm{ENaC}$-mediated entry step, as discussed below.

\section{Path for $\mathrm{Cl}^{-}$Absorption}

Isotonic absorption of fluid and salt in response to electrochemical driving forces generated by active $\mathrm{Na}^{+}$transport requires a $\mathrm{Cl}^{-}$conductance. $\mathrm{Cl}^{-}$is predicted to diffuse across the epithelium through available cellular and paracellular routes. The paracellular path of airway epithelia has the properties of free solution (Cotton et al. 1983). The further observation that the ratio of $\mathrm{Cl}^{-}$to mannitol trans-epithelial permeability coefficients exceeds the ratio of their free solution diffusivities suggests that a trans-cellular, in addition to a paracellular, route is available for passive $\mathrm{Cl}^{-}$diffusion (Stutts et al. 1988). Trans-cellular cellular $\mathrm{Cl}^{-}$ absorption requires $\mathrm{Cl}^{-}$entry across the apical membrane. Although most work on the elements of $\mathrm{Cl}^{-}$movement across airway epithelia has focused on $\mathrm{Cl}^{-}$secretion, ion channels in the apical cell membrane including CFTR and other $\mathrm{Cl}^{-}$channels, such as ano1, provide an apical $\mathrm{Cl}^{-}$conductance for $\mathrm{Cl}^{-}$to enter or leave the cell, depending on the existing $\mathrm{Cl}^{-}$electrochemical potential (Willumsen et al. 1989; Tarran et al. 2002; Ferrera et al. 2010). Moreover, airway epithelia express SLC family members that exchange intracellular $\mathrm{HCO}_{3}^{-}$for extracellular $\mathrm{Cl}^{-}$(Mount and Romero 2004). $\mathrm{Cl}^{-}$movement from cell to interstitium is thought to require a $\mathrm{Cl}^{-}$basolateral cell membrane conductance, for which electrophysiological data exist, but for which no molecular identity is known (Reddy and Quinton 1992; Uyekubo et al. 1998).

\section{Relationship between $\mathrm{Na}^{+}$Absorption and $\mathrm{Cl}^{-}$Secretion in Airways}

Studies in thin film preparations confirm that both $\mathrm{Na}^{+}$absorption and $\mathrm{Cl}^{-}$secretion are used to control the depth of liquid on the airway surface (Tarran et al. 2002, 2006). This duality of salt transport mechanisms is extensively documented in studies of freshly excised airway epithelia of many species (Olver et al. 1975), including human (Boucher et al. 1991). Ion flux data from decades of studies show an absorption flux of $\mathrm{Na}^{+}$that exceeds passive backflux under both short circuit and open circuit conditions (Boucher 1994a,b; Mall 2009), consistent with a classic passive $\mathrm{Na}^{+}$entry from the luminal solution via $\mathrm{ENaC}$ with active extrusion of $\mathrm{Na}^{+}$by the basolateral $\mathrm{Na}^{+} / \mathrm{K}^{+}$ATPase (Ussing et al. 1974). This net flux is eliminated by amiloride-like ENaC blockers and by ouabain, an inhibitor of the $\mathrm{Na}^{+} / \mathrm{K}+$ pump (Olver et al. 1975). The same studies have characterized $\mathrm{Cl}^{-}$ secretion by airway epithelia as a secondary active ion transport process (Olver et al. 1975; Boucher et al. 1980). That is, $\mathrm{Cl}^{-}$is not actively transported per se but is accumulated in airway cells above its predicted electrochemical potential by a basolateral cotransporter that use $\mathrm{Na}^{+}, \mathrm{K}^{+}$, and $\mathrm{Cl}^{-}$gradients supported by the $\mathrm{Na}^{+} / \mathrm{K}^{+}$pump (Frizzell et al. 1979). Passive $\mathrm{Cl}^{-}$conductance in the apical membrane allows 
M.M. Reddy and M.J. Stutts

$\mathrm{Cl}^{-}$accumulated above its electrochemical potential to exit into the luminal solution, creating net $\mathrm{Cl}^{-}$secretory transport (cf. Frizzell and Hanrahan 2013). Consistent with the passive nature of this process, $\mathrm{Cl}^{-}$secretion by airway epithelia responds to maneuvers that hyperpolarize the apical membrane potential. Such maneuvers prominently include $\mathrm{Na}^{+}$channel blockers and clamping trans-epithelial potential difference to zero (so-called short circuit conditions). Even so, under open circuit conditions and in the absence of amiloride, net absorption of both $\mathrm{Na}^{+}$and $\mathrm{Cl}^{-}$has been documented in native human (Knowles et al. 1984) and canine bronchial epithelium (Boucher et al. 1981).

\section{Water Permeability of Airway Epithelia}

A striking characteristic of airway epithelia that sets it apart from sweat ductal epithelia is its significant water permeability (Matsui et al. 2000; Verkman et al. 2000). Decreased water permeability is detected in alveoli and airways mice with knocked-down expression of aquaporins, but ASL hydration was unaffected (Verkman 2007). This result was attributed to the relatively small flux of water across airway epithelia, compared with the overall non-aquaporin routes available for water diffusion across airway epithelia (AS 2007). Accordingly, water permeability is not expected to be limiting for fluid absorption by airway epithelia.

\section{Regulation of ENaC}

Net salt and fluid absorption, that is, the net of active $\mathrm{Na}^{+}$absorption (with passive $\mathrm{Cl}^{-}$) and $\mathrm{Cl}^{-}$secretion (with passive $\mathrm{Na}^{+}$), is determined by the driving forces established in response to $\mathrm{Na}^{+}$conductance of the apical membrane. When $\mathrm{Cl}^{-}$conductance is predominant owing to the activation of CFTR and $\mathrm{Na}^{+}$conductance is blocked or very small, the apical membrane should hyperpolarize sufficiently to support $\mathrm{Cl}^{-}$secretion. As $\mathrm{Na}^{+}$conductance increases, the apical cell membrane must depolarize and diminish the driving force on $\mathrm{Cl}^{-}$to passing from cell to lumen (secretion). At some point as $\mathrm{Na}^{+}$conductance increases, the net driving force on $\mathrm{Cl}^{-}$reverses and $\mathrm{Cl}^{-}$is no longer secreted but moves in the absorptive direction to support net $\mathrm{Na}^{+}$and $\mathrm{Cl}^{-}$(and fluid) absorption. Because apical $\mathrm{Na}^{+}$conductance is principally due to $\mathrm{ENaC}$, with a small component of nonselective cation conductance of uncertain molecular origin, regulation of $\mathrm{ENaC}$ in airway epithelia is effectively the regulator of fluid absorption.

\section{ENaC Structure and Stoichiometry}

$\mathrm{ENaC}$ is a heteromeric channel composed of $\alpha-$, $\beta$-, and $\gamma$-subunits (Canessa et al. 1994b). Each subunit has two membrane-spanning regions with short amino and carboxyl cytoplasmic tails. The membrane-spanning regions of each subunit are joined by a large extracellular domain (Canessa et al. 1994b). ENaC belongs to a family of channels with similar topology that include acid-sensing channels (ASICs) (Kellenberger and Schild 2002). ASIC1 has been crystallized, revealing a homotrimeric structure (Jasti et al. 2007). This was taken as a strong indication that $\mathrm{ENaC}$ has a trimeric structure of $\alpha-, \beta$-, and $\gamma$-subunits (Stockand et al. 2008), but at this time, $\mathrm{ENaC}$ stoichiometry remains a controversial question (Anantharam and Palmer 2007).

$\mathrm{ENaC}$ trafficking to and from the apical membrane involves regulated processes that determine the density of ENaC in the apical membrane (Palmer et al. 2012). Liddle's disease of inherited amiloride-sensitive hypertension is caused by mutations in the carboxy-terminal cytosolic tails of $\beta$ - and $\gamma$-ENaC, which contain highly conserved PY protein interaction motifs that mediate the association of $\mathrm{ENaC}$ with the E3 ubiquitin ligase, Nedd4-L (Schild et al. 1996; Staub et al. 2000). Nedd4-L catalyzes ubiquitinylation of $\mathrm{ENaC}$ cytosolic amino-terminal lysines, and this posttranslational modification causes ENaC internalization (Rotin 2000). Numerous signaling pathways, including SGK1, PKA, and MAP kinases, adjust the strength of the ENaC-Nedd4-L association through the phosphorylation status of specific residues, giving rise to wide tissue variability 
in the impact of this regulatory axis (Debonnevilles et al. 2001). For example, the hypertension of patients with Liddle's disease is attributed to excess $\mathrm{ENaC}$ at the apical membrane of renal tubules (Palmer et al. 2012). However, Liddle's disease patients show no evidence of increased $\mathrm{Na}^{+}$absorption in respiratory epithelia (Knowles and Boucher 2002), suggesting that other mechanisms exist for controlling $\mathrm{Na}^{+}$conductance in certain tissues. Nonetheless, Nedd4-L must provide the underlying mechanism of retrieval of $\mathrm{ENaC}$ from the surface of airway epithelial cells, because mice with lung-specific Nedd4-L knockdown developed $\mathrm{Na}^{+}$hyperabsorption and fatal lung disease (Kimura et al. 2011).

$\mathrm{ENaC}$ activity at the apical membrane is also subject to regulation by signaling that influences channel open probability $\left(P_{\mathrm{O}}\right)$. ENaC is stimulated by proteases that cleave sites within the extracellular domains of $\mathrm{ENaC}$ (Vuagniaux et al. 2000; Hughey et al. 2004). This action acutely increases $P_{\mathrm{O}}$ (Caldwell et al. 2004, 2005). Although still not completely understood, it now appears that cleavage at defined sites within the extracellular domains of $\alpha$ - and $\gamma$-ENaC results in conformational changes that allow greater stability of the open state of the channel (Kashlan et al. 2011). It is also evident that numerous proteases can cleave and activate $\mathrm{ENaC}$ and that their catalytic activity is opposed by cognate protease inhibitors (Myerburg et al. 2008; Passero et al. 2008; Svenningsen et al. 2009). Thus, the stimulation of $\mathrm{ENaC}$ through extracellular proteolysis is likely to be intricately balanced and will depend on the coincidence of proteases and inhibitor expression with $\mathrm{ENaC}$.

$\mathrm{ENaC} P_{\mathrm{O}}$ is strongly stimulated by binding to membrane phosphoinositides through basic residues in the cytosolic amino termini, especially $\beta$ - and $\gamma$-ENaC (Ma et al. 2002; Yue et al. 2002). Numerous reports have established that exogenous PIP2 or PIP3 is a strong stimulate of $\mathrm{ENaC}$, such that signaling mechanisms that affect the abundance of these phosphoinositides clearly influence $\mathrm{ENaC}$-mediated $\mathrm{Na}^{+}$ absorption (Kunzelmann et al. 2004; Wang et al. 2008).

\section{Regulation of ASL Depth by Embedded Signals in Normal and CF Airways}

ENaC-mediated $\mathrm{Na}^{+}$conductance strongly affects the electrical potential difference across the apical membrane of airway epithelia (Willumsen et al. 1989; Willumsen and Boucher 1991), which determines the balance between isotonic fluid absorption and fluid secretion. Tarran and others, using "thin film" or "air-liquid interface" culture techniques, showed that airway cells cultured under conditions that mimic the $\sim 10-\mu \mathrm{m}$ depth of ASL maintained in vivo rely on soluble signals in the small volume on the culture surface to regulate $\mathrm{ENaC}$ (Tarran et al. 2001, 2005; Song et al. 2009). In fact, this work identified both protease inhibitors as well as nucleotides as the major inhibitory regulators of ENaC. As ASL depth is reduced, the concentration of these $\mathrm{ENaC}$ inhibitory signals increases, slowing $\mathrm{NaCl}$ absorption (Myerburg et al. 2006, 2010; Tarran et al. 2006). Moreover, ATP can stimulate $\mathrm{Ca}^{2+}$-dependent $\mathrm{Cl}^{-}$conductance in the apical membrane, and adenosine arising from the catabolism of ATP can stimulate CFTR activity. With ENaC inhibited, driving forces for $\mathrm{Cl}^{-}$secretion can be achieved. In this manner, airway epithelia can temper, or even reverse, the absorption of $\mathrm{NaCl}$ and $\mathrm{H}_{2} \mathrm{O}$ to maintain optimal airway surface hydration. These approaches revealed a striking difference between ASL homeostasis in differentiated cultures derived from normal and $\mathrm{CF}$ airways. $\mathrm{CF}$ cultures were unable to switch from absorption to secretion, leading to collapse of ASL depth (Tarran et al. 2006). This result was not unpredicted, given the absence of CFTR to mediate $\mathrm{Cl}^{-}$secretion in the CF cultures. However, it was also clear that $\mathrm{ENaC}$ remained hyperactive, even as ASL height decreased. A potential basis for $\mathrm{ENaC}$ hyperactivity in $\mathrm{CF}$ was detected in two laboratories as a much greater extent of $\mathrm{ENaC}$ cleavage in differentiated $\mathrm{CF}$ cultures compared with normal cultures (Myerburg et al. 2006; Gentzsch et al. 2010). Coexpression of CFTR in Xenopus oocytes with $\mathrm{ENaC}$ strongly depressed $\mathrm{ENaC}$ proteolysis and amiloride-sensitive currents. Taken together, these results confirm the role of CFTR-mediated $\mathrm{Cl}^{-}$secretion in 
M.M. Reddy and M.J. Stutts

homeostatic control of ASL volume and further implicate loss of CFTR-mediated inhibition of $\mathrm{ENaC}$ proteolysis/stimulation as a potential cause of the dysregulated $\mathrm{Na}^{+}$absorption that has been reported in CF airways.

\section{REFERENCES}

* Reference is also in this collection.

Anantharam A, Palmer LG. 2007. Determination of epithelial $\mathrm{Na}^{+}$channel subunit stoichiometry from singlechannel conductances. J Gen Physiol 130: 55-70.

Anderson MP, Berger HA, Rich DP, Gregory RJ, Smith AE, Welsh MJ. 1991. Nucleoside triphosphates are required to open the CFTR chloride channel. Cell 67: 775-784.

Barbero GJ, Sibinga MS. 1962. Enlargement of the submaxillary salivary glands in cystic fibrosis. Pediatrics 29: 788-793.

Baxter PS, Dickson JAS, Variend S, Taylor CJ. 1988. Intestinal disease in cystic fibrosis. Arch of Dis Child 63: 14961497.

Baxter PS, Read NW, Hardcastle PT, Wilson AJ, Hardcastle J, Taylor CJ. 1989. Abnormal jejunal potential difference in cystic fibrosis. Lancet 464-466.

Baxter P, Goldhill J, Hardcastle J, Hardcastle PT, Taylor CJ. 1990a. Enhanced intestinal glucose and alanine transport in cystic fibrosis. Gut 31: 817-820.

Baxter PS, Goldhill J, Hardcastle J, Hardcastle PT, Taylor CJ. 1990b. Enhanced intestinal glucose and alanine transport in cystic fibrosis. Gut 31: 817-820.

Berger HA, Travis SM, Welsh MJ. 1993. Regulation of the cystic fibrosis transmembrane conductance regulator $\mathrm{Cl}^{-}$ channel by specific protein kinases and protein phosphatases. J Biol Chem 268: 2037-2047.

Bergler MK, Dorin JR, Porteous DJ, Quinton PM. 1994a Defective salivary gland function in the $\mathrm{CF}$ mouse reveals three distinct phenotypes. Ped Pulmon 10: 211.

Bergler MK, Dorin JR, Porteous DJ, Quinton PM. 1994b. Defective salivary gland function in the CF mouse. European Cystic Fibrosis Conference Paris, France, June.

Berschneider HM, Azizhan RG, Knowles M, Boucher RC, Powell DW. 1987. Intestinal electrolyte in cystic fibrosis. Gastroenterology 92: 1315.

Berschneider HM, Knowles MR, Azizkhan RJ, Boucher RC, Tobey NA, Orlando RC, Powell DW. 1988. Altered intestinal chloride transport in cystic fibrosis. FASEB $J$ 2: 2625-2629.

Bhalla V, Hallows KR. 2008. Mechanisms of ENaC regulation and clinical implications. J Am Soc Nephrol 19: $1845-1854$.

Bijman J, Quinton PM. 1984. Influence of abnormal Cl impermeability on sweating in cystic fibrosis. Am J Physiol 247: C3-C9.

Blomfield J, Warton KL, Brown JM. 1973. Flow rate and inorganic components of submandibular saliva in cystic fibrosis. Arch Dis Child 48: 267-274.

Boucher RC. 1994a. Human airway ion transport. Part one. Am J Respir Crit Care Med 150: 271-281.
Boucher RC. 1994b. Human airway ion transport. Part two. Am J Respir Crit Care Med 150: 581-593.

Boucher RC. 2001. Pathogenesis of cystic fibrosis airways disease. Trans Am Clin Climatol Assoc 112: 99-107.

Boucher RC Jr, Bromberg PA, Gatzy JT. 1980. Airway transepithelial electric potential in vivo: Species and regional differences. J Appl Physiol 48: 169-176.

Boucher RC, Stutts MJ, Gatzy JT. 1981. Regional differences in bioelectric properties and ion flow in excised canine airways. J Appl Physiol 51: 706-714.

Boucher RC, Cotton CU, Gatzy JT, Knowles MR, Yankaskas JR. 1988. Evidence for reduced $\mathrm{Cl}^{-}$and increased $\mathrm{Na}^{+}$permeability in cystic fibrosis human primary cell cultures. J Physiol (Paris) 405: 77-103.

Boucher RC, Chinet T, Willumsen N, Knowles MR, Stutts MJ. 1991. Ion transport in normal and CF airway epithelia. Adv Exp Med Biol 290: 105-115.

Bradford EM, Sartor MA, Gawenis LR, Clarke LL, Shull GE. 2009. Reduced NHE3-mediated $\mathrm{Na}^{+}$absorption increases survival and decreases the incidence of intestinal obstructions in cystic fibrosis mice. Am J Physiol Gastrointest Liver Physiol 296: G886-G898.

Briel M, Greger R, Kunzelmann K. 1998. $\mathrm{Cl}^{-}$transport by cystic fibrosis transmembrane conductance regulator (CFTR) contributes to the inhibition of epithelial $\mathrm{Na}^{+}$ channels (ENaCs) in Xenopus oocytes co-expressing CFTR and ENaC. J Physiol 508: 825-836.

Caldwell RA, Boucher RC, Stutts MJ. 2004. Serine protease activation of near-silent epithelial $\mathrm{Na}^{+}$channels. Am J Physiol Cell Physiol 286: C190-C194.

Caldwell RA, Boucher RC, Stutts MJ. 2005. Neutrophil elastase activates near-silent epithelial $\mathrm{Na}^{+}$channels and increases airway epithelial $\mathrm{Na}^{+}$transport. Am J Physiol Lung Cell Mol Physiol 288: L813-L819.

Canessa CM, Merillat AM, Rossier BC. 1994a. Membrane topology of the epithelial sodium channel in intact cells. Am J Physiol 267: C1682-C1690.

Canessa CM, Schild L, Buell G, Thorens B, Gautschi I, Horisberger JD, Rossier BC. 1994b. Amiloride-sensitive epithelial $\mathrm{Na}^{+}$channel is made of three homologous subunits. Nature 367: 463-467.

Catalan MA, Nakamoto T, Gonzalez-Begne M, Camden JM, Wall AM, Clarke LL, Melvin JE. 2010. Cftr and ENaC ion channels mediate $\mathrm{NaCl}$ absorption in the mouse submandibular gland. J Physiol 588: 713-724.

Chen JH, Stoltz DA, Karp PH, Ernst SE, Pezzulo AA, Moninger TO, Rector MV, Reznikov LR, Launspach JL, Chaloner K, et al. 2010. Loss of anion transport without increased sodium absorption characterizes newborn porcine cystic fibrosis airway epithelia. Cell 143: 911-923.

Cheng SH, Rich DP, Marshall J, Gregory RJ, Welsh MJ, Smith AE. 1991. Phosphorylation of the R domain by cAMP-dependent protein kinase regulates the CFTR chloride channel. Cell 66: 1027-1036.

Clauss W, Dürr J, Skadhauge E, Hörnicke H. 1985. Effects of aldosterone and dexamethasone on apical membrane properties and Na-transport of rabbit distal colon in vitro. Pflugers Arch 403: 186-192.

Cook DI, Dinudom A, Komwatana P, Young JA. 1998. Control of $\mathrm{Na}^{+}$transport in salivary duct epithelial cells by cytosolic $\mathrm{Cl}^{-}$and $\mathrm{Na}^{+}$. Eur J Morphol 36: 67-73. 
Cotton CU, Lawson EE, Boucher RC, Gatzy JT. 1983. Bioelectric properties and ion transport of airways excised from adult and fetal sheep. J Appl Physiol 55: 1542-1549.

Cuthbert AW, MacVinish LJ, Hickman ME, Ratcliff R, Colledge WH, Evans NJ. 1994. Ion-transporting activity in the murine colonic epithelium of normal animals and animals with cystic fibrosis. Pflugers Arch 428: 508-515.

Cuthbert AW, Hickman ME, MacVinish LJ. 1999. Formal analysis of electrogenic sodium, potassium, chloride and bicarbonate transport in mouse colon epithelium. Br J Pharmacol 126: 358-364.

Davies H, Bagg J, Muxworthy S, Goodchild MC, McPherson MA. 1989. Electrolyte concentrations in control and cystic fibrosis submandibular saliva. Biochem Soc Trans 18: $447-448$.

Davies H, Bagg J, Goodchild MC, McPherson MA. 1991. Defective regulation of electrolyte and protein secretion in submandibular saliva of cystic fibrosis patients. Acta Paediatr Scand 80: 1094-1095.

Debongnie JC, Phillips SF. 1978. Capacity of the human colon to absorb fluid. Gastroenterology 74: 698-703.

Debonneville C, Flores SY, Kamynina E, Plant PJ, Tauxe C, Thomas MA, Münster C, Chraïbi A, Pratt JH, Horisberger JD, et al. 2001. Phosphorylation of Nedd4-2 by Sgk1 regulates epithelial $\mathrm{Na}^{+}$channel cell surface expression. EMBO J 20: 7052-7059.

de La Rosa DA, Canessa CM, Fyfe GK, Zhang P. 2000. Structure and regulation of amiloride sensitive sodium channels. Annu Rev Physiol 62: 573-594.

Devuyst O, Guggino WB. 2002. Chloride channels in the kidney: Lessons learned from knockout animals. Am J Physiol Renal Physiol 283: F1176-F1191.

Dinudom A, Young JA, Cook DI. 1993. $\mathrm{Na}^{+}$and $\mathrm{Cl}^{-}$conductances are controlled by cytosolic $\mathrm{Cl}^{-}$concentration in the intralobular duct cells of mouse mandibular glands. J Membr Biol 135: 289-295.

di Sant'Agnese PA. 1956. Cystic fibrosis of the pancreas. Am J Med 21: 406-422.

Duc C, Farman N, Canessa MC, Bonvalet JP, Rossier BC. 1994. Cell-specific expression of epithelial sodium channel $\alpha, \beta$, and $\gamma$ subunits in aldosterone-responsive epithelia from the rat: Localization by in situ hybridization and immunocytochemistry. J Cell Biol 127: 1907-1921.

Dulhanty AM, Riordan JR. 1994. Phosphorylation by cAMP-dependent protein kinase causes a conformational change in the $\mathrm{R}$ domain of the cystic fibrosis transmembrane conductance regulator. Biochemistry 33: 4072-4079.

Ferrera L, Caputo A, Galletta LJ. 2010. TMEM16A protein: A new identity for $\mathrm{Ca}^{2+}$-dependent $\mathrm{Cl}^{-}$channels. Physiology 25: 357-363.

Fischer H, Illek B, Machen TE. 1998. Regulation of CFTR by protein phosphatase $2 \mathrm{~B}$ and protein kinase C. Pflugers Arch 436: 175-181.

Frase LL, Strickland AD, Kachel GW, Krejs GJ. 1985. Enhanced glucose absorption in the jejunum of patients with cystic fibrosis. Gastroenterology 88: 478-484.

French PJ, Bijman J, Edixhoven $M$, Vaandrager $A B$, Scholte BJ, Lohmann SM, Nairn AC, De Jonge HR. 1995. Isotype-specific activation of cystic fibrosis transmembrane conductance regulator-chloride channels by
cGMP-dependent protein kinase II. J Biol Chem 270: 26626-26631.

* Frizzell RA, Hanrahan JW. 2013. Physiology of epithelial chloride and fluid secretion. Cold Spring Harb Perspect Biol doi: 10.1101/cshperspect.a009563.

Frizzell RA, Field M, Schultz SG. 1979. Sodium-coupled chloride transport by epithelial tissues. Am J Physiol 263: $\mathrm{F} 1-\mathrm{F} 8$.

Fuller CM, Awayda MS, Arrate MP, Bradford AL, Morris RG, Canessa CM, Rossier BC, Benos DJ. 1995. Cloning of a bovine renal epithelial $\mathrm{Na}^{+}$cannel subunit. Am J Physiol 269: C641-C654.

Gadsby DC, Nairn AC. 1999. Control of CFTR channel gating by phosphorylation and nucleotide hydrolysis. Physiol Rev 79: S77-S107.

Gentzsch M, Dang H, Dang Y, Garcia-Caballero A, Suchindran H, Boucher RC, Stutts MJ. 2010. The cystic fibrosis transmembrane conductance regulator impedes proteolytic stimulation of the epithelial $\mathrm{Na}^{+}$channel. J Biol Chem 285: 32227-32232.

Goldman MJ, Anderson GM, Stolzenberg ED, Kari UP, Zaslof M, Wilson JM. 1997. Human $\beta$-defensin-1 is a salt-sensitive antibiotic in lung that is inactivated in cystic fibrosis. Cell 88: 553-560.

Grubb BR, Boucher RC. 1997. Enhanced colonic $\mathrm{Na}^{+}$absorption in cystic fibrosis mice versus normal mice. Am J Physiol 272: G393-G400.

Grubb BR, O’Neal WK, Ostrowski LE, Kreda SM, Button B, Boucher RC. 2012. Transgenic hCFTR expression fails to correct $\beta$-ENaC mouse lung disease. Am J Physiol Lung Cell Mol Physiol 302: L238-L247.

Guggino WB. 1999. Cystic fibrosis and the salt controversy. Cell 96: 607-610.

Hall RA, Ostedgaard LS, Premont RT, Blitzer JT, Rahman N, Welsh MJ, Lefkowitz RJ. 1998. A C-terminal motif found in the $\beta 2$-adrenergic receptor, $\mathrm{P} 2 \mathrm{Y} 1$ receptor and cystic fibrosis transmembrane conductance regulator determines binding to the $\mathrm{Na}^{+} / \mathrm{H}^{+}$exchanger regulatory factor family of PDZ proteins. Proc Natl Acad Sci 95: 8496-8501.

Hardcastle J, Taylor CJ, Hardcastle PT, Baxter PS, Goldhill J. 1990. Intestinal transport in cystic fibrosis (CF). Acta Univ Carol (Praha) 36: 157-158.

Hardcastle J, Harwood MD, Taylor CJ. 2004. Small intestinal glucose absorption in cystic fibrosis: A study in human and transgenic $\Delta \mathrm{F} 508$ cystic fibrosis mouse tissues. $J$ Pharm Pharmacol 56: 329-338.

Hughey RP, Bruns JB, Kinlough CL, Harkleroad KL, Tong Q, Carattino MD, Johnson JP, Stockand JD, Kleyman TR. 2004. Epithelial sodium channels are activated by furindependent proteolysis. J Biol Chem 279: 18111-18114.

Hummler E, Horisberger JD. 1999. Genetic disorders of membrane transport. V. The epithelial sodium channel and its implication in human disease. Am J Physiol 276: G567-G571

Itani OA, Chen JH, Karp PH, Ernst S, Keshavjee S, Parekh K, Klesney-Tait J, Zabner J, Welsh MJ. 2011. Human cystic fibrosis airway epithelia have reduced $\mathrm{Cl}^{-}$conductance but not increased $\mathrm{Na}^{+}$conductance. Proc Natl Acad Sci 108: $10260-10265$. 
M.M. Reddy and M.J. Stutts

Jasti J, Furukawa H, Gonzales EB, Gouaux E. 2007. Structure of acid-sensing ion channel 1 at $1.9 \AA$ resolution and low pH. 449: 316-323.

Jia Y, Mathews CJ, Hanrahan JW. 1997. Phosphorylation by protein kinase $\mathrm{C}$ is required for acute activation of cystic fibrosis transmembrane conductance regulator by protein kinase A. J Biol Chem 272: 4978-4984.

Johnson W. 1956. Salivary electrolytes in fibrocystic disease. Arch Dis Child 31: 477.

Joris L, Dab I, Quinton PM. 1993. Elemental composition of human airway surface fluid in healthy and diseased airways. Am Rev Respir Dis 148: 1633-1637.

Kashlan OB, Adelman JL, Okumura S, Blobner BM, Zuzek Z, Hughey RP, Kleyman TR, Grabe M. 2011. Constraint-based, homology model of the extracellular domain of the epithelial $\mathrm{Na}^{+}$channel $\alpha$ subunit reveals a mechanism of channel activation by proteases. J Biol Chem 286: 649-660.

Kellenberger S, Schild L. 2002. Epithelial sodium channel/ degenerin family of ion channels: A variety of functions for a shared structure. Physiol Rev 82: 735-767.

Kesimer M, Makhov AM, Griffith JD, Verdugo P, Sheehan JK. 2010. Unpacking a gel-forming mucin: A view of MUC5B organization after granular release. Am J Physiol Lung Cell Mol Physiol 298: L15-L22.

Kilburn K. 1974. Functional morphology of the distal lung. Int Rev Cytol 37: 153-270.

Kimura T, Kawabe H, Jiang C, Zhang W, Xiang YY, Lu C, Salter MW, Brose N, Lu WY, Rotin D. 2011. Deletion of the ubiquitin ligase Nedd4L in lung epithelia causes cystic fibrosis-like disease. Proc Natl Acad Sci 108: 3216-3221.

Knowles MR, Boucher RC. 2002. Mucus clearance as a primary innate defense mechanism for mammalian airways. J Clin Invest 109: 571-577.

Knowles M, Murray G, Shallal J, Askin F, Ranga V, Gatzy J, Boucher R. 1984. Bioelectric properties and ion flow across excised human bronchi. J Appl Physiol 56: 868877.

Knowles MR, Robinson JM, Wood RE, Pue CA, Mentz MW, Wager GC, Gatzy JT, Boucher RC. 1997. Ion composition of airway surface liquid of patients with cystic fibrosis as compared with normal and disease-control subjects. $J$ Clin Invest 100: 2588-2595.

Ko YH, Pedersen PL. 1995. The first nucleotide binding fold of the cystic fibrosis transmembrane conductance regulator can function as an active ATPase. J Biol Chem 270: 22093-22096.

Kokko JP. 1973. Proximal tubule potential difference dependence on glucose, $\mathrm{HCO}_{3}^{-}$and amino acids. J Clin Invest 52: 1362-1367.

Kreda SM, Mall M, Mengos A, Rochelle L, Yankaskas J, Riordan JR, Boucher RC. 2005. Characterization of wild-type and $\Delta$ F508 cystic fibrosis transmembrane regulator in human respiratory epithelia. Mol Biol Cell 16: 2154-2167.

Kunzelmann K, Mall M. 2001. Pharmacotherapy of the ion transport defect in cystic fibrosis. Clin Exp Pharmacol Physiol 28: 857-867.

Kunzelmann K, Mall M. 2002. Electrolyte transport in the mammalian colon: Mechanisms and implications for disease. Physiol Rev 82: 245-289.
Kunzelmann K, Schreiber R, Boucherot A. 2001. Mechanisms of the inhibition of epithelial $\mathrm{Na}^{+}$channels by CFTR and purinergic stimulation. Kidney Int 60: 455461.

Kunzelmann K, Bachhuber T, Regeer R, Markovich D, Sun J, Schreiber R. 2004. Purinergic inhibition of the epithelial $\mathrm{Na}^{+}$transport via hydrolysis of PIP2. FASEB J 19: $142-143$.

Luo J, Pato MD, Riordan JR, Hanrahan JW. 1998. Differential regulation of single CFTR channels by PP2C, PP2A, and other phosphatases. Am J Physiol 274: C1397C1410.

Ma HP, Saxena S, Warnock DG. 2002. Anionic phospholipids regulate native and expressed epithelial sodium channel (ENaC). J Biol Chem 277: 7641-7644.

Mall MA. 2009. Role of the amiloride-sensitive epithelial $\mathrm{Na}^{+}$channel in the pathogenesis and as a therapeutic target for cystic fibrosis lung disease. Exp Physiol 94: $171-174$.

Mall M, Bleich M, Kuehr J, Brandis M, Greger R, Kunzelmann K. 1999. CFTR-mediated inhibition of epithelial $\mathrm{Na}^{+}$conductance in human colon is defective in cystic fibrosis. Am J Physiol 277: G709-G716.

Matsui H, Davis CW, Tarran R, Boucher RC. 2000. Osmotic water permeabilities of cultured, well-differentiated normal and cystic fibrosis airway epithelia. J Clin Invest 105: 1419-1427.

McPherson MA, Davies H, Mills CL, Pereira MMC, Goodchild MC, Dormer RL. 1992. Role of CFTR in salivary secretion. Elsevier, Amsterdam.

Mohammad-Panah R, Demolombe S, Riochet D, Leblais V, Loussouarn G, Pollard H, Baro I, Escande D. 1998. Hyperexpression of recombinant CFTR in heterologous cells alters its physiological properties. Am J Physiol 274: C310-C318.

Mount DB, Romero MF. 2004. The SLC26 gene family of multifunctional anion exchangers. Pflugers Arch 447: $710-721$.

Myerburg MM, Butterworth MB, McKenna EE, Peters KW, Frizzell RA, Kleyman TR, Pilewski JM. 2006. Airway surface liquid volume regulates $\mathrm{ENaC}$ by altering the serine protease-protease inhibitor balance. J Biol Chem 281: 27942-27949.

Myerburg MM, McKenna EE, Luke CJ, Frizzell RA, Kleyman TR, Pilewski JM. 2008. Prostasin expression is regulated by airway surface liquid volume and is increased in cystic fibrosis. Am J Physiol Lung Cell Mol Physiol 294: L932-L941.

Myerburg MM, Harvey PR, Heidrich EM, Pilewski JM, Butterworth MB. 2010. Acute regulation of $\mathrm{ENaC}$ in airway epithelia by proteases and trafficking. Am J Respir Cell Mol Biol 43: 712-719.

Olver RE, Davis B, Marin MG, Nadel JA. 1975. Active transport of $\mathrm{Na}^{+}$and $\mathrm{Cl}^{-}$across the canine tracheal epithelium in vitro. Am Rev Respir Dis 112: 811-815.

Ostedgaard LS, Meyerholz DK, Chen JH, Pezzulo AA, Karp PH, Rokhlina T, Ernst SE, Hanfland RA, Reznikov LR, Ludwig PS, et al. 2011. The $\Delta$ F508 mutation causes CFTR misprocessing and cystic fibrosis-like disease in pigs. Sci Transl Med 3: 74ra24. 
Palmer L, Patel A, Frindt G. 2012. Regulation and dysregulation of epithelial $\mathrm{Na}^{+}$channels. Clin Exp Nephrol 16: $35-43$.

Passero CJ, Mueller GM, Rondon-Berrios H, Tofovic SP, Hughey RP, Kleyman TR. 2008. Plasmin activates epithelial $\mathrm{Na}^{+}$channels by cleaving the $\gamma$ subunit. J Biol Chem 283: 36586-36591.

Picciotto MR, Cohn JA, Bertuzzi G, Greengard P, Nairn AC. 1992. Phosphorylation of the cystic fibrosis transmembrane conductance regulator. J Biol Chem 267: 1274212752.

Pilewski JM, Frizzell RA. 1999. Role of CFTR in airway disease. Physiol Rev 79: S215-S255.

Prader A, Gautier E. 1955. Die $\mathrm{Na}^{-}$and $\mathrm{K}^{-}$Konzentration in gemischten Speichel: II Erhohte Werte bei der Pankreasfibrose. Helv Paediat Acta 10: 56.

Quinton PM. 1984. Exocrine glands. In Cystic fibrosis (ed. Taussig LM), pp. 338-375. Thieme-Stratton, New York.

Quinton PM. 1987. Physiology of sweat secretion. Kidney Int Suppl 21: S102-S108.

Quinton PM. 1990. Cystic fibrosis: A disease in electrolyte transport. FASEB J 4: 2709-2717.

Quinton PM. 1999. Physiological basis of cystic fibrosis: A historical perspective. Physiol Rev 79: S3-S22.

Quinton PM. 2007. Cystic fibrosis: Lessons from the sweat gland. Physiology (Bethesda) 22: 212-225.

Quinton PM, Reddy MM. 1991. Regulation of absorption in the human sweat duct. Adv Exp Med Biol 290: 159-170.

Randak C, Neth P, Auerswald EA, Eckerskorn C, AssfalgMachleidt I, Machleidt W. 1997. A recombinant polypeptide model of the second nucleotide-binding fold of the cystic fibrosis transmembrane conductance regulator functions as an active ATPase, GTPase and adenylate kinase. FEBS Lett 410: 180-186.

Reddy MM, Quinton PM. 1987. Intracellular potentials of microperfused human sweat duct cells. Pflugers Arch 410: 471-475.

Reddy MM, Quinton PM. 1989. Altered electrical potential profile of human reabsorptive sweat duct cells in cystic fibrosis. Am J Physiol 257: C722-C726.

Reddy MM, Quinton PM. 1991. Intracellular potassium activity and the role of potassium in transepithelial salt transport in the human reabsorptive sweat duct. J Membr Biol 119: 199-210.

Reddy MM, Quinton PM. 1992. cAMP activation of CFaffected $\mathrm{Cl}^{-}$conductance in both cell membranes of an absorptive epithelium. J Membr Biol 130: 49-62.

Reddy MM, Quinton PM. 1994. Intracellular Cl activity: Evidence of dual mechanisms of $\mathrm{cl}$ absorption in sweat duct. Am J Physiol 267: C1136-C1144.

Reddy MM, Quinton PM. 1996. Hydrolytic and nonhydrolytic interactions in the ATP regulation of CFTR $\mathrm{Cl}^{-}$ conductance. Am J Physiol 271: C35-C42.

Reddy MM, Quinton PM. 2002. Influence of cytoplasmic $\mathrm{Cl}^{-}$on the effect of CFTR activation on ENaC function. Pediatr Pulmonology 34 (Suppl): 8-359.

Reddy MM, Quinton PM. 2003a. Functional interaction of $\mathrm{CFTR}$ and $\mathrm{ENaC}$ in sweat glands. Pflugers Arch 445: 499-503.
Reddy MM, Quinton PM. 2003b. Control of dynamic CFTR selectivity by glutamate and ATP in epithelial cells. $\mathrm{Na}$ ture 423: 756-760.

Reddy MM, Light MJ, Quinton PM. 1999. Activation of the epithelial $\mathrm{Na}^{+}$channel $(\mathrm{ENaC})$ requires $\mathrm{CFTR} \mathrm{Cl}^{-}$channel function. Nature 402: 301-304.

Reddy MM, Wang XF, Quinton PM. 2008. Effect of cytosolic $\mathrm{pH}$ on epithelial $\mathrm{Na}^{+}$channel in normal and cystic fibrosis sweat ducts. J Membr Biol 225: 1-11.

Reuss L. 1985. Changes in cell volume measured with an electrophysiologic technique. Proc Natl Acad Sci 82: 6014-6018.

Reuss L, Segal Y, Altenberg G. 1991. Regulation of ion transport across gallbladder epithelium. Annu Rev Physiol 53: 361-373.

Riordan JR, Rommens JM, Kerem B, Alon N, Rozmahel R, Grzelczak Z, Zielenski J, Lok S, Plavsic N, Chou JL, et al. 1989. Identification of the cystic fibrosis gene: Cloning and characterization of complementary DNA. Science 245: 1066-1073.

Rossier BC. 1996. The renal epithelial sodium channel: New insights in understanding hypertension. Adv Nephrol Necker Hosp 25: 275-286.

Rotin D. 2000. Regulation of the epithelial sodium channel (ENaC) by accessory proteins. Curr Opin Nephrol Hypertens 9: 529-534.

Russo MA, Hogenauer C, Coates SW Jr, Santa Ana CA, Porter JL, Rosenblatt RL, Emmett M, Fordtran JS. 2003. Abnormal passive chloride absorption in cystic fibrosis jejunum functionally opposes the classic chloride secretory defect. J Clin Invest 112: 118-125.

Sato K, Sato F. 1984. Defective $\beta$ adrenergic response of cystic fibrosis sweat glands in vivo and in vitro. J Clin Invest 73: 1763-1771.

Schild L, Canessa CM, Shimkets RA, Gautschi I, Lifton RP Rossier BC. 1995. A mutation in the epithelial sodium channel causing Liddle disease increases channel activity in the Xenopus laevis oocyte expression system. Proc Natl Acad Sci 92: 5699-5703.

Schild L, Lu Y, Gautschi I, Schneeberger E, Lifton RP, Rossier BC. 1996. Identification of a PY motif in the epithelial $\mathrm{Na}$ channel subunits as a target sequence for mutations causing channel activation found in Liddle syndrome. EMBO J 15: 2381-2387.

Schreiber R, Hopf A, Mall M, Greger R, Kunzelmann K. 1999. The first-nucleotide binding domain of the cystic-fibrosis transmembrane conductance regulator is important for inhibition of the epithelial $\mathrm{Na}^{+}$channel. Proc Natl Acad Sci 96: 5310-5315.

Schwiebert EM, Benos DJ, Egan ME, Stutts MJ, Guggino WB. 1999. CFTR is a conductance regulator as well as a chloride channel. Physiol Rev 79: S145-S166.

Sheppard DN, Welsh MJ. 1999. Structure and function of the CFTR chloride channel. Physiol Rev 79: S23-S45.

Short DB, Trotter KW, Reczek D, Kreda SM, Bretscher A, Boucher RC, Stutts MJ, Milgram SL. 1998. An apical PDZ protein anchors the cystic fibrosis transmembrane conductance regulator to the cytoskeleton. J Biol Chem 273: 19797-19801. 
M.M. Reddy and M.J. Stutts

Smith JJ, Travis SM, Greenberg EM, Welsh MJ. 1996. Cystic fibrosis airway epithelia fail to kill bacteria because of abnormal airway surface fluid. Cell 85: 229-236.

Song Y, Namkung W, Nielson DW, Lee JW, Finkbeiner WE, Verkman AS. 2009. Airway surface liquid depth measured in ex vivo fragments of pig and human trachea: Dependence on $\mathrm{Na}^{+}$and $\mathrm{Cl}^{-}$channel function. Am J Physiol Lung Cell Mol Physiol 297: L1131-L1140.

Staub O, Abriel H, Plant P, Ishikawa T, Kanelis V, Saleki R, Horisberger JD, Schild L, Rotin D. 2000. Regulation of the epithelial $\mathrm{Na}^{+}$channel by Nedd 4 and ubiquitination. Kidney Int 57: 809-815.

Stockand JD, Staruschenko A, Pochynyuk O, Booth RE, Silverthorn DU. 2008. Insight toward epithelial $\mathrm{Na}^{+}$ channel mechanism revealed by the acid-sensing ion channel 1 structure. IUBMB Life 60: 620-628.

Stutts MJ, Gatzy JT, Boucher RC. 1988. Activation of chloride conductance induced by potassium in tracheal epithelium. Pflugers Arch 411: 252-258.

Stutts MJ, Canessa CM, Olsen JC, Hamrick M, Cohn JA, Rossier BC, Boucher RC. 1995. CFTR as a cAMP-dependent regulator of sodium channels. Science 269: 847-850.

Svenningsen P, Uhrenholt TR, Palarasah Y, Skjødt K, Jensen BL, Skøtt O. 2009. Prostasin-dependent activation of epithelial $\mathrm{Na}^{+}$channels by low plasmin concentrations. Am J Physiol Regul Integr Comp Physiol 297: R1733-R1741.

Tarran R, Grubb BR, Gatzy JT, Davis CW, Boucher RC. 2001 The relative roles of passive surface forces and active ion transport in the modulation of airway surface liquid volume and composition. J Gen Physiol 118: 223-236.

Tarran R, Loewen ME, Paradiso AM, Olsen JC, Gray MA, Argent BE, Boucher RC, Gabriel SE. 2002. Regulation of murine airway surface liquid volume by CFTR and $\mathrm{Ca}^{2+}$. activated $\mathrm{Cl}^{-}$conductances. J Gen Physiol 120: 407-418.

Tarran R, Button B, Boucher RC. 2005. Regulation of normal and cystic fibrosis airway surface liquid volume by phasic shear stress. Annu Rev Physiol 68: 543-561.

Tarran R, Trout L, Donaldson SH, Boucher RC. 2006. Soluble mediators, not cilia, determine airway surface liquid volume in normal and cystic fibrosis. J Gen Physiol 127: 591-604.

Taylor CJ, Baxter PS, Hardcastle J, Hardcastle PT. 1987. Absence of secretory response in jejunal biopsy samples from children with cystic fibrosis. Lancet 330: 107-108.

Taylor CJ, Baxter PS, Hardcastle J, Hardcastle PT. 1988. Failure to induce secretion in jejunal biopsies from children with cystic fibrosis. Gut 29: 957-962.

Teune TM, Timmers-Reker AJ, Bouquet J, Bijman J, De Jonge HR, Sinaasappel M. 1996. In vivo measurement of chloride and water secretion in the jejunum of cystic fibrosis patients. Pediatr Res 40: 522-527.

Ussing HH, Erlij D, Lassen U. 1974. Transport pathways in biological membranes. Annu Rev Physiol 36: 17-49.

Uyekubo SN, Fischer H, Maminishkis A, Illek B, Miller SS, Widdicombe JH. 1998. cAMP-dependent absorption of chloride across airway epithelium. Am J Physiol 275: L1219-L1227.

Vaandrager AB, Ehlert EM, Jarchau T, Lohmann SM, de Jonge HR. 1996. N-terminal myristoylation is required for membrane localization of cGMP-dependent protein kinase type II. J Biol Chem 271: 7025-7029.

Vaandrager AB, Smolenski A, Tilly BC, Houtsmuller AB, Ehlert EM, Bot AG, Edixhoven M, Boomaars WE, Lohmann SM, de Jonge HR. 1998. Membrane targeting of cGMP-dependent protein kinase is required for cystic fibrosis transmembrane conductance regulator $\mathrm{Cl}^{-}$ channel activation. Proc Natl Acad Sci 95: 1466-1471.

Verkman AS. 2007. Role of aquaporins in lung liquid physiology. Respir Physiol Neurobiol 159: 324-330.

Verkman AS, Matthay MA, Song Y. 2000. Aquaporin water channels and lung physiology. Am J Physiol Lung Cell Mol Physiol 278: L867-L879.

Vuagniaux G, Vallet V, Jaeger NF, Pfister C, Bens M, Farman N, Courtois-Coutry N, Vandewalle A, Rossier BC, Hummler E. 2000. Activation of the amiloride-sensitive epithelial sodium channel by the serine protease mCAP1 expressed in a mouse cortical collecting duct cell line. J Am Soc Nephrol 11: 828-834.

Wang J, Knight ZA, Fiedler D, Williams O, Shokat KM, Pearce D. 2008. Activity of the p110- $\alpha$ subunit of phosphatidylinositol-3-kinase is required for activation of epithelial sodium transport. Am J Physiol Renal Physiol 295: F843-F850.

Welsh MJ. 1987. Electrolyte transport by airway epithelia. Physiol Rev 67: 1143-1184.

Welsh MJ. 1996. Cystic fibrosis. In Molecular biology of membrane transport disorders, 2nd ed. (ed. Schultz SG), Chapter 30, pp. 605-623. Springer, New York.

Welsh MJ, Anderson MP, Rich DP, Berger HA, Denning GM, Ostedgaard LS, Sheppard DN, Cheng SH, Gregory RJ, Smith AE. 1992. Cystic fibrosis transmembrane conductance regulator: A chloride channel with novel regulation. Neuron 8: 821-829.

Widdicombe JH, Widdicombe JG. 1995. Regulation of human airway surface liquid. Respir Physiol 99: 3-12.

Willumsen NJ, Boucher RC. 1991. Sodium transport and intracellular sodium activity in cultured human nasal epithelium. Am J Physiol 261: C319-C331.

Willumsen NJ, Davis CW, Boucher RC. 1989. Intracellular $\mathrm{Cl}^{-}$activity and cellular $\mathrm{Cl}^{-}$pathways in cultured human airway epithelium. Am J Physiol 256: C1033-C1044.

Yue G, Malik B, Yue G, Eaton DC. 2002. Phosphatidylinositol 4,5-bisphosphate (PIP2) stimulates epithelial sodium channel activity in A6 cells. J Biol Chem 277: 11965-11969.

Zabner J, Smith JJ, Karp PH, Widdicombe JH, Welsh MJ. 1998. Loss of CFTR chloride channels alters salt absorption by cystic fibrosis airway epithelia in vitro. Mol Cell 2: 397-403. 


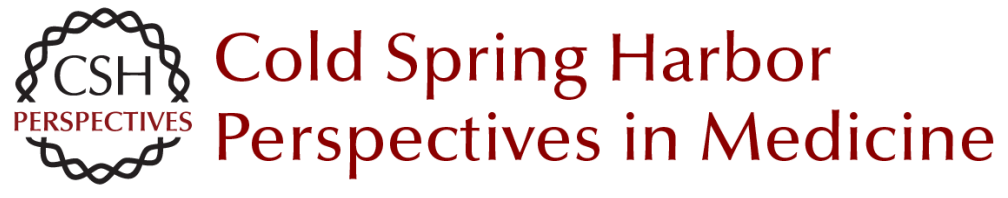

\section{Status of Fluid and Electrolyte Absorption in Cystic Fibrosis}

M.M. Reddy and M. Jackson Stutts

Cold Spring Harb Perspect Med 2013; doi: 10.1101/cshperspect.a009555

Subject Collection Cystic Fibrosis

Antibiotic and Anti-Inflammatory Therapies for

Cystic Fibrosis

James F. Chmiel, Michael W. Konstan and J. Stuart Elborn

Structure and Function of the Mucus Clearance System of the Lung

Brenda M. Button and Brian Button

New Pulmonary Therapies Directed at Targets

Other than CFTR

Scott H. Donaldson and Luis Galietta

The Cystic Fibrosis Airway Microbiome

Susan V. Lynch and Kenneth D. Bruce

\section{Cystic Fibrosis Transmembrane Conductance \\ Regulator (ABCC7) Structure \\ John F. Hunt, Chi Wang and Robert C. Ford}

Status of Fluid and Electrolyte Absorption in

Cystic Fibrosis

M.M. Reddy and M. Jackson Stutts

The Influence of Genetics on Cystic Fibrosis

Phenotypes

Michael R. Knowles and Mitchell Drumm

Perspectives on Mucus Properties and Formation

--Lessons from the Biochemical World

Daniel Ambort, Malin E.V. Johansson, Jenny K.

Gustafsson, et al.
The Cystic Fibrosis Intestine

Robert C. De Lisle and Drucy Borowitz

Cystic Fibrosis Transmembrane Regulator

Correctors and Potentiators

Steven M. Rowe and Alan S. Verkman

The Cystic Fibrosis of Exocrine Pancreas

Michael Wilschanski and Ivana Novak

Dynamics Intrinsic to Cystic Fibrosis

Transmembrane Conductance Regulator Function and Stability

P. Andrew Chong, Pradeep Kota, Nikolay V.

Dokholyan, et al.

The Cystic Fibrosis Gene: A Molecular Genetic

Perspective

Lap-Chee Tsui and Ruslan Dorfman

The CFTR Ion Channel: Gating, Regulation, and

Anion Permeation

Tzyh-Chang Hwang and Kevin L. Kirk

Assessing the Disease-Liability of Mutations in CFTR

Claude Ferec and Garry R. Cutting

Supramolecular Dynamics of Mucus Pedro Verdugo

For additional articles in this collection, see http://perspectivesinmedicine.cshlp.org/cgi/collection/ 